\title{
Short term effect of air pollution on mortality in Polish urban populations - what is different?
}

\author{
Bogdan Wojtyniak, Tomasz Piekarski
}

\begin{abstract}
Study objective - To assess, within the multinational European Community funded APHEA project, the relationship between daily ambient air pollution with sulphur dioxide $\left(\mathrm{SO}_{2}\right)$ and black smoke (BS) and the daily number of deaths from all causes except external, from cardiovascular diseases, and from respiratory diseases taking into account several possible confounding factors.
\end{abstract}

Design - Time series analysis with the application of Poisson regression to the counts of daily number of deaths from selected causes over several years. Data were obtained from the computer files of individual death records in four Polish cities. Criteria developed for all the centres participating in the project were applied to the process of model building.

Setting - Four Polish cities - Cracow (period 1977-89), Lodz (1977-90), Poznan (1983-90), and Wroclaw (1979-89).

Subjects - Permanent residents of the cities who died in a city of residence or in a surrounding region during the study period.

Main results - There were significant positive associations between mortality from all causes excluding external ones and $\mathrm{SO}_{2}$ and BS in Cracow and in Lodz and between mortality from cardiovascular diseases and $\mathrm{SO}_{2}$ in Cracow alone. In other cities the association was either non-significant or significant but in the opposite direction. No significant positive association was found between respiratory deaths and these pollutants.

Conclusions - Short term effect of air pollution on mortality in Polish urban population cannot be ignored. However, differences observed between the cities suggest that the association may be not so straightforward and therefore there is a need of further studies to identify additional factors that may modify and confound the association.

(f Epidemiol Comm Health 1996;50(Suppl 1):S36-S41)

Department of Medical Statistics, National Institute of

Hygiene, 00-791 Warsaw, Poland

B Wojtyniak
T Piekarski

Correspondence to: Dr B Wojtyniak. Europe and the USA which indicate that a pollutant in the atmosphere, especially of inhalable particulate matter, may result in an increase in mortality in the days following the episode, and that this occurs even at moderate or relatively low pollutant levels. ${ }^{1-10}$ The multinational European Community funded APHEA project ${ }^{11}$ created an excellent opportunity for us to assess whether similar effects can also be observed in the different socioeconomic and environmental conditions prevailing in our country.

The basis of our study was the network of Sanitary-Epidemiological Stations of the Ministry of Health, which for years have been collecting data on atmospheric air pollution in Poland. For our purpose we identified six large stations in major Polish cities with a long tradition of measuring the air pollution concentration. After reviewing the suitability of the data for the project (completeness of the measurements and temporal stability of the sampling sites), four cities were selected: Cracow, Lodz, Poznan, and Wroclaw. The cities are among the largest in Poland and have populations that range between 500000 and 800000 permanent residents. In 1979 the areas covered by the cities were 322, 214, 229, and $293 \mathrm{~km}^{2}$ for Cracow, Lodz, Poznan and Wroclaw respectively. The cities are in a group of those whose major sources of air pollution are industrial (including coal fired power plants) and community - local heating systems and household sources (coal fired stoves are still used for heating in older houses).

\section{Methods}

THE DATA SET

In each of the selected cities the air pollution concentrations have been measured for years in networks of sampling units, the number of which varied over time and was different in each city. Nevertheless, in each we were able to identify three manually operated units working in fixed places in different parts of a city. We used data from 24 hour measurements of sulphur dioxide $\left(\mathrm{SO}_{2}\right)$ (in Cracow the method was titration with sodium tetraborate after absorption in hydrogen peroxide and in the other three cities colorimetric method with p-rosaniline was used) and of black smoke (BS) (reflectometric method was used in all the cities). The measurements were taken in the periods 1977-89 in Cracow, 1977-90 in Lodz, 1983-90 in Poznan, and 1979-89 in Wroclaw. To represent better the average condition in a city and to avoid too many days with missing data (when some monitors were not operating due to maintenance work) we used mean concentrations of $\mathrm{SO}_{2}$ and $\mathrm{BS}$ from three locations in the analysis. The proportions of days with all three measurements were in ranges $77-83 \%$ for $\mathrm{SO}_{2}$ and $75-79 \%$ for BS and the proportions of days with no measurements were in a range 
Table 1 Mean values of daily data on mortality, air pollution, and meteorology in Cracow (1977-89), Lodz (1977-90), Poznan (1983-90), and Wroclaw (1979-89)

\begin{tabular}{|c|c|c|c|c|c|c|c|c|c|c|c|c|c|}
\hline \multirow[t]{2}{*}{ Variables and centiles } & & \multicolumn{3}{|l|}{ Cracow } & \multicolumn{3}{|l|}{ Lodz } & \multicolumn{3}{|l|}{ Poznan } & \multicolumn{3}{|l|}{ Wroclaw } \\
\hline & & All & Cold & Warm & All & Cold & Warm & All & Cold & Warm & All & Cold & Warm \\
\hline \multicolumn{14}{|l|}{$\begin{array}{l}\text { Cause of death: } \\
\text { All cause }\end{array}$} \\
\hline All cause & $\begin{array}{l}10 \\
50\end{array}$ & $\begin{array}{l}11 \\
16\end{array}$ & $\begin{array}{l}12 \\
17\end{array}$ & $\begin{array}{l}10 \\
15\end{array}$ & $\begin{array}{l}19 \\
26\end{array}$ & $\begin{array}{l}20 \\
27\end{array}$ & $\begin{array}{l}18 \\
25\end{array}$ & $\begin{array}{l}11 \\
16\end{array}$ & $\begin{array}{l}12 \\
17\end{array}$ & $\begin{array}{l}10 \\
15\end{array}$ & $\begin{array}{r}8 \\
12\end{array}$ & $\begin{array}{r}8 \\
13\end{array}$ & $\begin{array}{r}7 \\
12\end{array}$ \\
\hline & 90 & 22 & 23 & 21 & 34 & 35 & 33 & 22 & 23 & 21 & 17 & $\begin{array}{l}13 \\
18\end{array}$ & $\begin{array}{l}12 \\
17\end{array}$ \\
\hline \multirow{3}{*}{ Cardiovascular system } & 10 & 4 & 5 & 4 & 9 & 10 & 8 & 5 & 6 & 5 & 3 & 4 & 3 \\
\hline & 50 & 8 & 9 & 8 & 14 & 15 & 14 & 9 & 10 & 8 & 7 & 7 & 6 \\
\hline & 90 & 13 & 14 & 12 & 20 & 21 & 19 & 14 & 14 & 13 & 10 & 11 & 10 \\
\hline \multirow[t]{3}{*}{ Respiratory system } & 10 & 0 & 0 & 0 & 0 & 0 & 0 & 0 & 0 & 0 & 0 & 0 & 0 \\
\hline & 50 & 0 & 1 & 0 & 1 & 1 & 1 & 1 & 1 & 0 & 0 & 1 & 0 \\
\hline & 90 & 2 & 2 & 2 & 3 & 3 & 3 & 2 & 2 & 2 & 2 & 2 & 1 \\
\hline \multirow[t]{3}{*}{ Digestive system } & 10 & 0 & 0 & 0 & 0 & 0 & 0 & 0 & 0 & 0 & 0 & 0 & 0 \\
\hline & 50 & 0 & 0 & 0 & 1 & 1 & 1 & 0 & 0 & 0 & 0 & 0 & 0 \\
\hline & 90 & 2 & 2 & 2 & 3 & 3 & 3 & 2 & 2 & 2 & 2 & 2 & 2 \\
\hline \multicolumn{14}{|l|}{ Pollutant: } \\
\hline \multirow[t]{2}{*}{$\mathrm{SO}_{2}$} & 10 & $\begin{array}{l}30 \cdot 0 \\
74 \cdot 1\end{array}$ & $\begin{array}{r}59 \cdot 4 \\
110 \cdot 0\end{array}$ & $\begin{array}{l}24 \cdot 7 \\
49 \cdot 6\end{array}$ & $13 \cdot 3$ & $\begin{array}{l}40 \cdot 5 \\
84 \cdot 1\end{array}$ & $11 \cdot 0$ & $10 \cdot 3$ & $\begin{array}{l}35 \cdot 1 \\
83 \cdot 8\end{array}$ & $\begin{array}{r}8 \cdot 0 \\
8 \cdot 7\end{array}$ & $8 \cdot 3$ & $22 \cdot 0$ & $7 \cdot 0$ \\
\hline & $\begin{array}{l}50 \\
90\end{array}$ & $\begin{array}{l}14 \cdot 1 \\
170 \cdot 0\end{array}$ & $203 \cdot 3$ & $\begin{array}{r}49 \cdot 0 \\
100 \cdot 0\end{array}$ & $\begin{array}{r}43 \cdot 1 \\
123 \cdot 3\end{array}$ & $\begin{array}{r}84.1 \\
153 \cdot 7\end{array}$ & $\begin{array}{l}20 \cdot 3 \\
51 \cdot 7\end{array}$ & $\begin{array}{r}41 \cdot 0 \\
131 \cdot 3\end{array}$ & $\begin{array}{r}83.8 \\
177.0\end{array}$ & $\begin{array}{l}24 \cdot 7 \\
72 \cdot 0\end{array}$ & $\begin{array}{l}29 \cdot 0 \\
83 \cdot 1\end{array}$ & $\begin{array}{r}53.6 \\
120.7\end{array}$ & $\begin{array}{l}19 \cdot 7 \\
41 \cdot 7\end{array}$ \\
\hline \multirow{3}{*}{ Black smoke } & 10 & $25 \cdot 6$ & $67 \cdot 4$ & $20 \cdot 0$ & $20 \cdot 3$ & $52 \cdot 7$ & $16 \cdot 3$ & $9 \cdot 3$ & $23 \cdot 7$ & $7 \cdot 3$ & $25 \cdot 7$ & $42 \cdot 2$ & $22 \cdot 0$ \\
\hline & 50 & $73 \cdot 3$ & $146 \cdot 7$ & $40 \cdot 0$ & $57 \cdot 3$ & $100 \cdot 5$ & $31 \cdot 3$ & $34 \cdot 0$ & $57 \cdot 0$ & $22 \cdot 3$ & $54 \cdot 3$ & $89 \cdot 0$ & $42 \cdot 3$ \\
\hline & 90 & $246 \cdot 7$ & $316 \cdot 7$ & 80.0 & $150 \cdot 5$ & $185 \cdot 7$ & $64 \cdot 3$ & $92 \cdot 0$ & $127 \cdot 3$ & $60 \cdot 0$ & $141 \cdot 3$ & $190 \cdot 0$ & $82 \cdot 3$ \\
\hline \\
\hline \multirow{3}{*}{ Temperature } & 10 & $-3 \cdot 3$ & $-6 \cdot 3$ & $7 \cdot 4$ & $-2 \cdot 8$ & $-5 \cdot 9$ & $7 \cdot 2$ & $-1 \cdot 2$ & $-5 \cdot 7$ & $7 \cdot 0$ & $-2 \cdot 0$ & $-6 \cdot 2$ & $6 \cdot 9$ \\
\hline & 50 & $\begin{array}{r}8 \cdot 5 \\
18 \cdot 0\end{array}$ & $1 \cdot 6$ & $14 \cdot 7$ & $\begin{array}{r}8 \cdot 3 \\
\end{array}$ & $1 \cdot 7$ & $14 \cdot 3$ & $\begin{array}{r}9 \cdot 4 \\
\end{array}$ & $1 \cdot 7$ & $13 \cdot 9$ & $9 \cdot 0$ & $1 \cdot 3$ & $14 \cdot 1$ \\
\hline & $\begin{array}{l}90 \\
10\end{array}$ & $\begin{array}{l}18 \cdot 0 \\
66 \cdot 0\end{array}$ & $\begin{array}{r}9 \cdot 3 \\
\end{array}$ & $19 \cdot 7$ & $18 \cdot 3$ & $\begin{array}{r}9 \cdot 2 \\
\end{array}$ & $20 \cdot 1$ & 18.4 & $7 \cdot 2$ & $20 \cdot 0$ & $18 \cdot 6$ & $7 \cdot 3$ & $20 \cdot 0$ \\
\hline \multirow{2}{*}{ Humidity } & 50 & $\begin{array}{l}00 \cdot 9 \\
80 \cdot 1\end{array}$ & $84 \cdot 0$ & $\begin{array}{l}03 \cdot 1 \\
76 \cdot 2\end{array}$ & $\begin{array}{l}03.0 \\
81.5\end{array}$ & $\begin{array}{l}72 \cdot 9 \\
86 \cdot 2\end{array}$ & $\begin{array}{l}39.4 \\
75.9\end{array}$ & $\begin{array}{l}61 \cdot 2 \\
79 \cdot 2\end{array}$ & $\begin{array}{l}71 \cdot 6 \\
85 \cdot 2\end{array}$ & $\begin{array}{l}57 \cdot 6 \\
74 \cdot 6\end{array}$ & $\begin{array}{l}65 \cdot 7 \\
80 \cdot 1\end{array}$ & $\begin{array}{l}72 \cdot 7 \\
85 \cdot 2\end{array}$ & $\begin{array}{l}63 \cdot 4 \\
76 \cdot 0\end{array}$ \\
\hline & 90 & 92.0 & 93.5 & $88 . \overline{9}$ & $93 \cdot 4$ & 95.0 & 89.5 & 92.0 & $93 \cdot \overline{6}$ & $88 \cdot 7$ & $92 \cdot 1$ & $94 \cdot \overline{1}$ & 89.0 \\
\hline
\end{tabular}

$0 \cdot 5-4 \%$ and $0 \cdot 2-4 \%$ for $\mathrm{SO}_{2}$ and $\mathrm{BS}$ respectively.

Data on all deaths in Poland have been collected by the Central Statistical Office using death certificates completed by physicians. The underlying cause of death is recorded with the 3-digit code of International Classification of Diseases and Causes of Death. The data files with individual death records have been computerised since 1970 and the completeness of the files is practically $100 \%$. Death records of permanent residents of Cracow, Lodz, Poznan, and Wroclaw who died in a city of residence or the surrounding region (voivodship) were extracted from these files and then files with the counts of deaths during each day of a study period were created. Four groups of causes of deaths were considered: all deaths without external causes, deaths from diseases of the circulatory system (ICD 8 and 9 codes 390$458 / 9$ ), deaths from diseases of the respiratory system (codes 460-519), and deaths from diseases of the digestive system (codes 520-577/ 9 ). The last group was considered a control group.

Data on potential confounding factors included the average 24 hour temperature and relative humidity (based on one measurement site in each city) were obtained from the Institute of Meteorology and Water Management which is responsible for operating of the meteorological measurements network in Poland. Influenza epidemics were identified from biweekly reports from the SanitaryEpidemiological Stations on the number of influenza cases in the region. Because the exact numbers of cases may be inaccurate, we used only a binary "yes-no" variable to represent such a period in the analysis.

STATISTICAL ANALYSIS

Poisson regression was used to estimate the relationship between air pollution and daily deaths. In the analysis we followed the procedure for model building developed for all the centres participating in the project and presented in detail in a separate report. In general, all models include long term trend components (linear and quadratic), dummy variables for the years that significantly modified long term trend, seasonal pattern components (sinusoidal terms up to 6 th order), dummy variable for influenza epidemic periods (not significant and not present in the models for mortality from diseases of the digestive system), and dummy variables for day of the week. Temperature was controlled for by linear and quadratic terms and humidity by a linear term only. Meterological variables might have been lagged by up to two days. Holidays were not included in the final models since dummy variables representing them were non-significant in a model building process. After trying linear, logarithmic, and square root transformations of air pollution variables, log transformed values of $\mathrm{SO}_{2}$ and $\mathrm{BS}$ were used in the analysis. Lags up to three days and averages of consecutive lags up to three days of air pollution variables were checked and for the final model the lag with largest adjusted $\mathbf{R}^{2}$ in the linear regression model was used. In all steps of the analysis we used procedures of the SAS System. ${ }^{12}$

\section{Results}

After eliminating days with missing values for air pollution and meteorological conditions, the study periods comprised 4747 days in Cracow, 5112 days in Lodz, 2863 days in Poznan, and 4017 days in Wroclaw. The average number of deaths per day during the study periods was largest in Lodz (27 deaths), was smaller and similar in Cracow and Poznan (17 deaths), and was smallest in Wroclaw (13). Table 1 presents the average (median), 10th, and 90th centiles 
Table 2 Adjusted $R^{2}$ of final linear autoregressive models without air pollutants

\begin{tabular}{lllll}
\hline Town & Cause of death & & \\
\cline { 2 - 5 } & All cause & $\begin{array}{l}\text { Cardiovascular } \\
\text { system }\end{array}$ & Respiratory system & Digestive system \\
\hline Cracow & $0 \cdot 1633$ & $0 \cdot 2265$ & $0 \cdot 057$ & $0 \cdot 0125$ \\
Lodz & $0 \cdot 2418$ & $0 \cdot 255$ & $0 \cdot 0638$ & $0 \cdot 0124$ \\
Poznan & $0 \cdot 1032$ & $0 \cdot 1082$ & 0.069 & $0 \cdot 0202$ \\
Wroclaw & $0 \cdot 1492$ & $0 \cdot 1448$ & $0 \cdot 0442$ & $0 \cdot 0076$ \\
\hline
\end{tabular}

of number of deaths in relation to causes considered in the analysis and season that is, cold for November, December, January, February, and March, and warm otherwise. In all the cities number of daily deaths was greater in the cold than in warm season. In $10 \%$ of the days with the highest mortality the number of all deaths was about twice as large as in $10 \%$ of days with the lowest mortality. For cardiovascular diseases, the ratio was even larger. The average number of deaths from respiratory and digestive systems diseases was less than 1 .

Air pollution levels for both $\mathrm{SO}_{2}$ and $\mathrm{BS}$ were the highest in Cracow, where the respective median daily concentrations were $74 \cdot 1$ and $73.3 \mu \mathrm{g} / \mathrm{m}^{3}$ respectively, and in $10 \%$ of days concentrations exceeded 170 and $246 \mu \mathrm{g} / \mathrm{m}^{3}$ for $\mathrm{SO}_{2}$ and $\mathrm{BS}$ respectively. Lodz was the second worst city, while Poznan had the lowest BS level and Wroclaw lowest $\mathrm{SO}_{2}$ level. As can be seen in table 1 , in all the cities there were clear seasonal differences in air pollution levels for both pollutants. In the winter season, the average levels of $\mathrm{SO}_{2}$ were two to four times higher and the BS levels were two to three times higher than in the other months. However, even in the cold season on $10 \%$ of days with the highest pollution, concentrations were three to five times above levels observed in $10 \%$ of the least polluted days. Temperature and humidity were similar in the cities.

Results of the final ordinary regression models with the confounding factors only show that the fit of particular models depended on the cause of deaths as well as on the city (table 2 ). The fit was much better for deaths from cardiovascular causes and all causes without external than for respiratory and digestive diseases. For the first two groups of causes, the model fits the data better in Lodz and Cracow than in Poznan and Wroclaw. However, in all cases the analysis of the residuals did not reveal any systematic pattern and the hypothesis that the series represented white noise could not have been rejected.

The results of the final Poisson models for $\mathrm{SO}_{2}$ and $\mathrm{BS}$ are presented in table 3. A significant positive association of both the pollutants with mortality due to all causes without external was observed in Cracow and Lodz. In addition, mortality from diseases of the circulatory system was also associated with the $\mathrm{SO}_{2}$ level, but only in Cracow. Three results are rather surprising - the significant positive association of deaths from diseases of the digestive system with BS in Cracow and the significant but negative association of deaths from all causes and cardiovascular causes with $\mathrm{SO}_{2}$ and from respiratory system diseases with BS in Wroclaw. In Wroclaw other lags in the models for these diseases were not significant, but all had negative signs.

As can be seen in figures 1 and 2 , significant relative risks associated with a twofold increase in air pollution levels were low, and moreover were slightly lower for $\mathrm{BS}$ than $\mathrm{SO}_{2}$ (for all

Table 3 Final results of Poisson regression for pollution variables

\begin{tabular}{|c|c|c|c|c|c|c|c|c|}
\hline \multirow{3}{*}{$\begin{array}{l}\text { Cause of death } \\
\text { Cracow: } \\
\text { All cause }\end{array}$} & \multirow{3}{*}{$\begin{array}{l}\mathrm{SO}_{2} \\
\\
\mathrm{~S} 1 \\
\mathrm{~S} 0-3\end{array}$} & \multirow[t]{2}{*}{ Estimate } & \multicolumn{2}{|l|}{$(95 \% C I)$} & \multirow[t]{2}{*}{$B S$} & \multirow[t]{2}{*}{ Estimate } & \multicolumn{2}{|l|}{$(95 \% C I)$} \\
\hline & & & & & & & & \\
\hline & & $\begin{array}{l}0.0253 \\
0.0401\end{array}$ & $\begin{array}{l}0.0072, \\
0.0173\end{array}$ & $\begin{array}{l}0.0434) \\
0.0630)\end{array}$ & $\begin{array}{l}\text { B2 } \\
\text { B0-3 }\end{array}$ & $\begin{array}{l}0.0183 \\
0.0208\end{array}$ & $\begin{array}{r}0.0012, \\
(-0.0006\end{array}$ & $\begin{array}{l}0.0355) \\
0.0422)\end{array}$ \\
\hline \multirow{2}{*}{ Cardiovascular system } & so & 0.0381 & ( 0.0125 , & 0.0638 ) & Bo & 0.0105 & $(-0.0136$ & 0.0346 ) \\
\hline & So-3 & 0.0544 & ( 0.0220 , & $0.0868)$ & B0-3 & 0.0202 & $(-0.0095$, & $0.0498)$ \\
\hline \multirow{2}{*}{ Respiratory system } & & -0.0345 & $(-0.1244$, & $0.0555)$ & B1 & -0.0153 & $(-0.0989$, & $0.0682)$ \\
\hline & S0-1 & -0.0589 & $(-0 \cdot 1600$ & $0.0421)$ & B0-1 & -0.0388 & $(-0.1306$, & 0.0530 ) \\
\hline \multirow{2}{*}{ Digestive system } & S1 & 0.0484 & $(-0.0358$ & $0 \cdot 1326)$ & B1 & 0.0831 & ( 0.0119 , & $0 \cdot 1544)$ \\
\hline & Lodz: & 0.0282 & $(-0.0704$ & $0 \cdot 1268)$ & B0-1 & $0 \cdot 0848$ & ( 0.0091, & $0 \cdot 1605)$ \\
\hline \multirow[t]{2}{*}{ All cause } & S2 & 0.0213 & ( 0.0054 & $0.0372)$ & B3 & 0.0176 & ( 0.0039 & $0.0313)$ \\
\hline & S0-3 & 0.0235 & ( 0.0034 , & $0.0436)$ & B0-3 & 0.0080 & $(-0.0096$, & $0.0256)$ \\
\hline \multirow{2}{*}{ Cardiovascular system } & S2 & 0.0196 & $(-0.0014$ & $0.0406)$ & B2 & 0.0073 & $(-0.0112$, & $0.0258)$ \\
\hline & S0-3 & 0.0173 & $(-0.0092$, & $0.0438)$ & B0-3 & 0.0042 & $(-0.0195$, & $0.0279)$ \\
\hline \multirow[t]{2}{*}{ Respiratory system } & S1 & -0.0124 & $(-0.0844$ & $0.0596)$ & B1 & $-0 \cdot 0485$ & $(-0 \cdot 1089$ & $0 \cdot 0120)$ \\
\hline & $\begin{array}{l}\text { S0-1 } \\
\text { S1 }\end{array}$ & -0.0406 & $(-0 \cdot 1212$ & $0.0399)$ & B0-1 & $\begin{array}{l}-0.0490 \\
-0.0240\end{array}$ & $(-0.1166$, & $\begin{array}{l}0.0186) \\
0.0353)\end{array}$ \\
\hline Digestive system & $\begin{array}{l}\text { S1 } \\
\text { S0-1 }\end{array}$ & $\begin{array}{r}-0.0093 \\
0.0209\end{array}$ & $\begin{array}{l}(-0.0784, \\
(-0.0557,\end{array}$ & $\begin{array}{l}0.0597) \\
0.0975)\end{array}$ & $\begin{array}{l}\text { B1 } \\
\text { B0-1 }\end{array}$ & $\begin{array}{l}-0.0240 \\
-0.0099\end{array}$ & $(-0.0760$ & 0.0562 ) \\
\hline \multirow{2}{*}{$\begin{array}{l}\text { Poznan: } \\
\text { All cause }\end{array}$} & & & & & & & & $0.0238)$ \\
\hline & $\begin{array}{l}\text { S1 } \\
\text { S0-1 }\end{array}$ & $\begin{array}{l}0.0072 \\
0.0064\end{array}$ & $\begin{array}{l}(-0.0041, \\
(-0.0059,\end{array}$ & $\begin{array}{l}0.0184) \\
0.0188)\end{array}$ & $\begin{array}{l}\text { B0 } \\
\text { B0-1 }\end{array}$ & $\begin{array}{r}0.0086 \\
-0.0021\end{array}$ & $\begin{array}{l}(-0.006 /, \\
(-0.0196,\end{array}$ & $0.0155)$ \\
\hline \multirow{2}{*}{ Cardiovascular system } & So & -0.0025 & $(-0.0170$ & $0.0120)$ & B2 & -0.0067 & $(-0.0267$, & $0.0133)$ \\
\hline & S0-1 & 0.0018 & $(-0.0144$, & $0.0179)$ & B0-1 & -0.0094 & $(-0.0321$, & $0.0133)$ \\
\hline \multirow[t]{2}{*}{ Respiratory system } & S2 & -0.0255 & $(-0.0703$, & $0.0192)$ & B0 & -0.0332 & $(-0.0944$, & $0.0280)$ \\
\hline & S0-2 & -0.0163 & $(-0.0701$, & $0.0375)$ & B0-3 & -0.0563 & $(-0.1369$, & $0.0244)$ \\
\hline \multirow[t]{2}{*}{ Digestive system } & S1 & 0.0295 & $(-0.0302$, & $0.0891)$ & B1 & 0.0704 & $(-0.0086$, & 0.1493 ) \\
\hline & S0-1 & 0.0295 & $(-0.0357$ & $0 \cdot 0948)$ & B0-2 & $0 \cdot 0701$ & $(-0.0282$ & $0 \cdot 1684)$ \\
\hline \multirow{2}{*}{$\begin{array}{l}\text { Wroclaw: } \\
\text { All cause }\end{array}$} & S2 & -0.0108 & $(-0.0204$ & $-0.0013)$ & B1 & 0.0059 & $(-0.0139$, & $0.0258)$ \\
\hline & S0-2 & -0.0091 & $(-0.0207$ & $0.0026)$ & B0-3 & -0.0051 & $(-0.0300$, & $0.0197)$ \\
\hline Cardiovascular system & S2 & -0.0135 & $(-0.0262$, & $-0.0008)$ & B1 & $0 \cdot 0072$ & $\begin{array}{l}(-0.0195, \\
(-0.0420\end{array}$ & $\begin{array}{l}0.0339) \\
0.0240)\end{array}$ \\
\hline \multirow{2}{*}{ Respiratory system } & $\begin{array}{l}\text { So-3 } \\
\text { So }\end{array}$ & $\begin{array}{r}-0.0126 \\
0.0236\end{array}$ & $\begin{array}{l}(-0.0291, \\
(-0.0203,\end{array}$ & $\begin{array}{l}0.0040) \\
0.0675)\end{array}$ & $\begin{array}{l}\mathrm{B} 0-3 \\
\mathrm{~B} 1\end{array}$ & $\begin{array}{l}-0.0090 \\
-0.1028\end{array}$ & $(-0.1870$ & $-0.0185)$ \\
\hline & So-1 & 0.0241 & $(-0.0246$ & $0.0729)$ & B0-3 & $-0 \cdot 1707$ & $(-0.2753$, & $-0.0662)$ \\
\hline \multirow[t]{2}{*}{ Digestive system } & S2 & -0.0119 & $(-0.0550$ & $0.0312)$ & B1 & -0.0096 & $(-0.0980$ & $0.0787)$ \\
\hline & So-3 & -0.0124 & $(-0.0679$, & $0.0430)$ & B0-1 & -0.0206 & $(-0.118$ & $0 \cdot 0776)$ \\
\hline
\end{tabular}

Si-ith lag of $\mathrm{SO}_{2}$; $\mathrm{S} 0$-i-mean of lags 0 through i; Bi-ith lag of black smoke; B0-i-mean of lags 0 through i. 


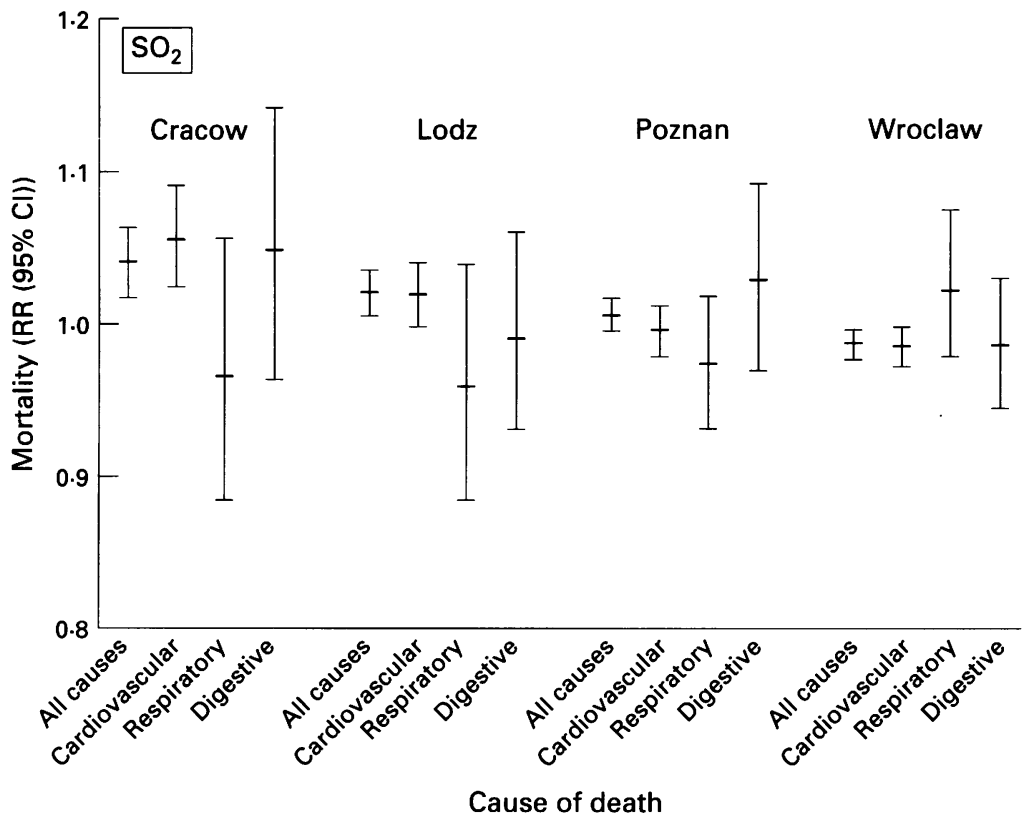

Figure 1 Relative risk of death (and 95\% CI) associated with twofold increase in the daily concentration of $\mathrm{SO}_{2}$.

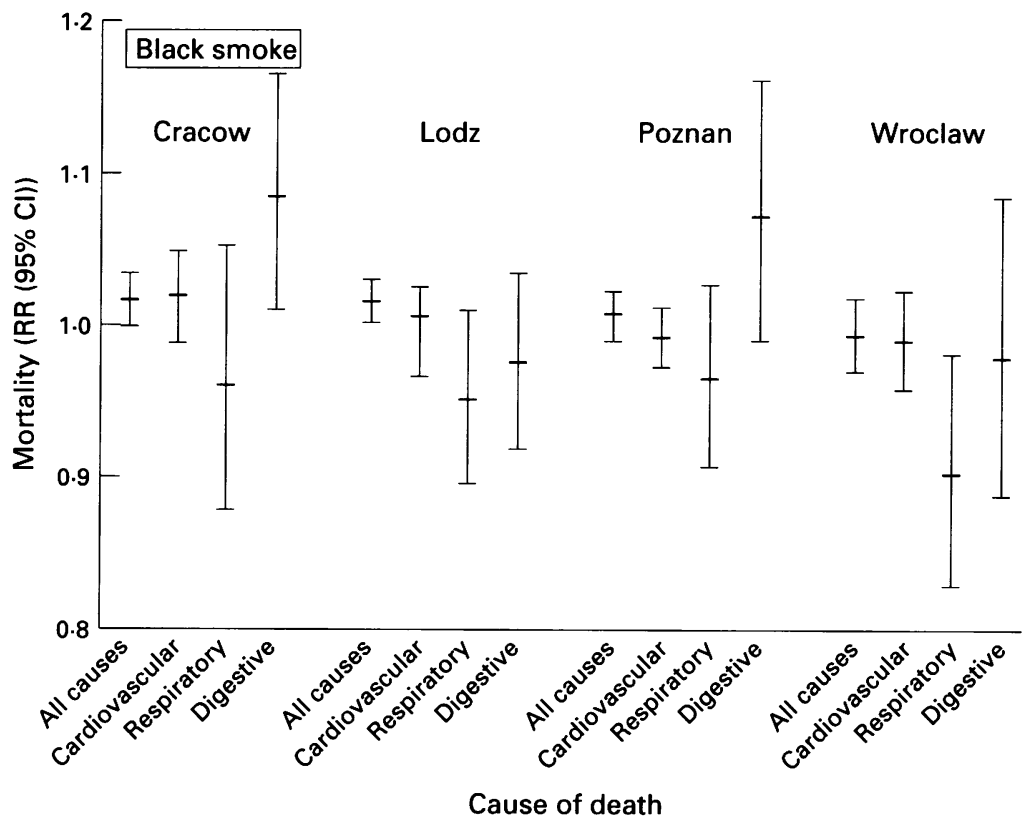

Figure 2 Relative risk of death (and 95\% CI) associated with twofold increase in the daily concentration of black smoke. nificant associations with both $\mathrm{SO}_{2}$ (S2= $0.0231,95 \%$ CI $0.0015,0.0446)$ and BS (B3 = $0.0192,95 \%$ CI $0.0002,0.0381$ ).

\section{Discussion}

In the light of results in the published reports and discussed, for instance, by Ostro, ${ }^{13}$ Schwartz, ${ }^{14}$ and Pope et al, ${ }^{15}$ our findings are slightly confusing. Recent results of Styer et $a l^{16}$ in two counties in the USA, however, also failed to show as much consistency as other studies. Three specific issues are important in our findings. Firstly, while in two cities, namely Cracow and Lodz, some negative effects of air pollution on mortality were observed, this was not true in the other two (Poznan and Wroclaw). Secondly, in none of the cities was a positive association between air pollution and mortality from respiratory diseases observed, while in some other studies this was found to be stronger than an association with general mortality. ${ }^{7817}$ Thirdly, when the air pollution effect was observed it was greater for $\mathrm{SO}_{2}$ than for BS, which contradicts the results from the US locations. ${ }^{18}$ However, in some European cities a significant association of $\mathrm{SO}_{2}$ with mortality was also observed. ${ }^{2310}$ We do not suggest that the pollutants considered act independently since their levels are correlated and the correlation coefficients of mean daily concentrations of $\mathrm{SO}_{2}$ and $\mathrm{BS}$ ranged from 0.61 in Wroclaw to 0.81 in Lodz. However, possible synergy between pollutants, between pollutants and meteorological conditions, and between pollutants and season will be analysed later, in the next stage of our study.

One of the strong points of the APHEA project from the point of view of comparability of the results and their future pooling was the standardised methodology of data management and analysis. However, it is possible that our inconsistent findings partly result from some patterns in our data that were not well dealt with by our core model and required a different method of modeling. Such a possibility will be checked in a separate analysis.

Inconsistency of our results also prompts a question about discrepancy in the data quality. However, we have no reason to suspect any major differences between the cities in this respect. Nor are there any differences in the collection systems for the mortality and the air pollution data. Registration of mortality in Poland is complete, whatever the place of residence, though some differences between regions in assigning the underlying cause of death may exist. When analysing causes of deaths in the four cities in 1989-90 we found marked differences in mortality rates from ischaemic heart disease and atherosclerosis. Age adjusted proportionate mortality rates for ischaemic heart disease were (in \%) $16 \cdot 1,11.0$, 24.5 , and $8 \cdot 1$ while those for atherosclerosis were $7 \cdot 9,15 \cdot 1,4 \cdot 7$, and $25 \cdot 6$ in Cracow, Lodz, Poznan, and Wroclaw respectively. Nevertheless, over the entire study period the proportions of deaths from diseases of the circulatory system were quite similar in the cities and varied from $49 \cdot 1 \%$ in Cracow to 
$53.1 \%$ in Poznan. It is unlikely that differences in cause specific mortality or in assigning the underlying cause of death could have been responsible for the variant results of the analysed relationship between air pollution and mortality. One shortcoming of our mortality data that has to be taken into account is related to information about administrative place of death. For so-called confidentiality reasons, the most specific information about geographical place of death in the data files that the Central Statistical Office renders accessible to external users is about a geographical region (voivodship) of deaths and there are 49 such units in Poland. Therefore in the analysis we had to consider deaths of residents of a selected city that took place not only in the city itself but also in the region whose capital was the city of residence. It is probable though, that only a few deaths occured outside the city of residence (especially when external causes are excluded) and there should have been little difference in this respect between the cities. Nevertheless, in the case of deaths due to respiratory diseases, whose daily number was small, even minimal distortion might have obscured true associations.

Air pollution measurements are taken according to the system run by the Sanitary Inspection of the Ministry of Health, and the Sanitary-Epidemiological Stations responsible for the measurements in the cities under study were considered among the best. The proportion of days with two or three measurements missing, which may suggest existing problems in creditable performance of the stations did not differ very much between the cities (for $\mathrm{SO}_{2}$ it was in a range $3 \cdot 1-6 \cdot 7 \%$ and for $\mathrm{BS}$ $3 \cdot 3-5 \cdot 4 \%$ ). It also seems reassuring that the parameters of models estimated after excluding days with air pollution above $200 \mu \mathrm{g} / \mathrm{m}^{3}$ which could have a particularly undesirable influence on the results had the measurements been erroneous did not change our general conclusions. Nevertheless, we have no formal grounds for stating that the quality of the measurements was the same in all the stations since at that time there was no system of interlaboratory quality control.

It is also possible that the average value of measurements from three sites was a better estimation of people's exposure to the pollutants in Cracow and Lodz than in Poznan and Wroclaw. However, there are no major differences in the locations of the measurement sites in the cities and with regard to the area, city Cracow and Wroclaw were in worse position as they are more widespread than Lodz and Poznan. Correlation coefficients of BS measurements in different stations were higher in Cracow and Lodz than in Poznan and Wroclaw but there was no such difference in the case of $\mathrm{SO}_{2}$. It seems that there is no basis for the above supposition as a possible cause of different findings in the cities.

Almost nothing is known about susceptible subjects in the study areas. The only indicator available is the size of the elderly population in the cities. This conforms only partly to the observed differences between study popu- lations in the air pollution-mortality association. In 1989 the largest proportion of the inhabitants aged 65 years and above was in Lodz $(12.9 \%)$ and the lowest was in Wroclaw $(9 \cdot 2 \%)$; however, in Poznan $(11 \cdot 1 \%)$ it was slightly higher than in Cracow $(10.0 \%)$. In addition, differences in total mortality levels in the analysed regions shed little light on the observed variation in the air pollution and mortality association. In 1989-90 the lowest age adjusted mortality rate was found in Cracow (570 per 100000 ) and the highest in Lodz (731 per 100000$)$

The other possible explanation for the differences observed between the cities could be inadequate characterisation of air pollution mixtures present in the cities by the indicator pollutants used. The general importance of this issue was raised regarding studies on air pollution and pulmonary function and respiratory symptoms in children. ${ }^{19}$ However, it has also been pointed out that the association between mortality and particulate air pollution had been observed over a large range of concentrations in a variety of communities with varying mixture of pollutants. ${ }^{20}$ The available data on emission of industrial air pollution suggest that there may be substantial differences in air pollution mixtures in the cities studied. ${ }^{21}$ For instance, in Cracow about $60 \%$ of emitted dust is ashes and about $25 \%$ is metallurgic dust, while in other cities dust is composed of some $90 \%$ ashes. In the case of emission of gaseous pollutants, in Crascow $\mathrm{SO}_{2}$ makes up only $10 \%$, while in Lodz this is about $85 \%$ and in Poznan and Wroclaw about $60 \%$. It seems that uncovering possible differences in air pollution mixtures in the cities under study is an important matter. It may help to determine more specific components responsible for the health effects observed in some of the Polish cities, which is probably small yet should not be neglected.

Finally, it could be hypothesised that the inconsistency of our results and the much weaker association between air pollution and mortality in Poland than in the USA and western European countries means that under different socioeconomic conditions and mortality levels increased because of other risk factors related to lifestyle, diet, occupational exposure, indoor environment etc, the outdoor air pollution level plays a smaller role as a health hazard for the general population. This hypothesis, which is important from the public health policy perspective needs additional analysis and further studies.

1 Mazumdar S, Schimmel H, Higgins ITT. Relation of daily mortality to air pollution: an analysis of 14 London winters, 1958/59-1971/72. Arch Environ Health 1982;37:213-20.

2 Hatzakis A, Katsouyanni K, Kalandidi A, Day N, Trichopoulos D. Short-term effects of air pollution on mortality in Athens. Int $\mathcal{F}$ Epidemiol 1986;15:73-81.

3 Derrienic F, Richardson S, Mollie A, Lellouch J. Short term effects of sulphur dioxide pollution on mortality in two French cities. Int $\mathcal{f}$ Epidemiol 1989;18:186-97.

4 Fairley D. The relationship of daily mortality to suspended particulates in Santa Clara county, 1980-86. Envimon Health Perspect 1990;89:159-68.

5 Kinney PL, Ozkaynak H. Associations of daily mortality and air pollution in Los Angeles county. Environ Res 1991; 54:99-120.

6 Pope CA III, Schwartz J, Ransom MR. Daily mortality and $\mathrm{PM}_{10}$ pollution in Utah Valley. Arch Environ Health 1992; 47:211-7. 
7 Schwartz J, Dockery DW. Particulate air pollution and daily mortality in Steubenville, Ohio. Am $\mathcal{f}$ Epidemiol 1992;135: $12-9$.

8 Schwartz J, Dockery DW. Increased mortality in Philadelphia associated with daily air pollution concentrations. Am Rev Respir Dis 1992;145:600-4.

9 Schwartz J. Air pollution and daily mortality in Birmingham, Alabama. Am 7 Epidemiol 1993;137:1136-47.

$10 \mathrm{Spix}$ C, Heinrich J, Dockery D et al. Air pollution and daily mortality in Erfurt, East Germany, 1980-1989. Environ Health Perspect 1993;101:518-26.

11 Katsouyanni K, Zmirou D, Spix C et al. Short-term effects of air pollution on health: a European approach using epidemiological time-series data. Eur Respir $\mathcal{f} 1995 ; 8$ : 1030-8.

12 SAS Institute Inc, SAS/STAT user's guide. Version 6, 4th ed. Cary, NC: SAS Institute Inc, 1989.

13 Ostro B. The association of air pollution and mortality: examining the case for inference. Arch Environ Health 1993;48:336-42.
14 Schwartz J. Air pollution and daily mortality: a review and meta-analysis. Environ Res 1994;64:36-52.

15 Pope CA, Bates DV, Raizenne ME. Health effects of particulate air pollution: time for reassessment? Environ Health Perspect 1995;103:472-80.

16 Styer P, McMillan N, Gao F, Davis J, Sacks J. Effect of outdoor airborne particulate matter on daily death counts. Environ Health Perspect 1995;103:490-7.

17 Schwartz J. What are people dying of on high air pollution days? Environ Res 1994;64:26-35.

18 Schwartz J. Particulate air pollution and daily mortality: a synthesis. Public Health Rev 1991/92;19:39-60.

19 Hoek G, Brunekreef B. Acute effects of a winter air pollution episode on pulmonary function and respiratory symptoms episode on pulmonary function and respiratory symp

20 Dockery DW, Schwartz J, Spengler JD. Air pollution and daily mortality: associations with particulates and acid aerosols. Environ Res 1992;59:362-73

21 Glowny Urzad Statystyczny (Central Statistical Office). Ochrona srodowiska 1989. Warszawa: Glowny Urzad Statystyczny, 1989. 